Literature Review

\title{
Fertility Outcomes after Laparoscopic Reversal of Tubal Sterilization
}

\author{
Luaran Fertilitas pada Restorasi Sterilisasi Tuba dengan Laparoskopi \\ Wachyu Hadisaputra, Lestari M. Rini, Yuven S. Pratama \\ Division of Reproductive Health Department of Obstetrics and Gynecology \\ Faculty of Medicine University of Indonesia/ \\ National General Hospital Dr. Cipto Mangunkusumo \\ Jakarta
}

\begin{abstract}
Objective: To know pregnancy outcome in the tubal reversal of sterilized women.

Method: Literature review.

Results: Sterilization is considered the most common contraception methods in United States of America, approximately 39\% women in reproductive age (15 - 44 years) used this method. However, approximately $15 \%$ of these patients deplored this decision due to the influence of their own environment and some factors, such as: young age, the death of a child, the disability of child, and change of partner/remarried. Tubal reanastomosis or tubal reversal is a surgical procedure that attempts to restore the fallopian tube patency following sterilization. To date, the modern procedure is performed by doing an excision of the tubal segment and reanastomosis by transabdominal laparoscopy. Recently, the laparoscopic technology has developed and evolved rapidly as the robotic assisted laparoscopy was invented. There is alternative method for restoring the fertility in sterilized women who regretted the decision of being sterilized. Unlike the tubal reversal which is conducted in order to restore the tubal function, the IVF is performed to bypass the function of tubes in fertility. The major advantage for laparoscopic surgery is short postoperative stay duration with minimal tissue handling, less postoperative adhesions, and diminish morbidity rate. Despite of its major drawback, high-cost of robotic machine and machine maintenance; there are advantages of robotic laparoscopy compared to the conventional laparoscopy, such as improved dexterity, more precise and accurate articulation, reduced tremor, and better visualization of the operating field. In vitro fertilization (IVF) is the hallmark in the era of assisted reproductive technology and became an alternative option to regain the fertility in sterilized women.
\end{abstract}

Conclusion: The pregnancy rate and live birth rate in laparoscopy, robotic and open surgery were relatively similar. Surgical reversal to women younger than 40 is recommended and laparoscopic reversal should be performed if the expertise is available. It is reasonable to counsel IVF to over 40 women.

[Indones J Obstet Gynecol 2012; 36-3: 154-60]

Keywords: gynecology, IVF, pregnancy outcomes, reanastomosis, robotic laparoscopy, tubal reversal

\section{Abstrak}

Tujuan: Untuk mengetahui hasil kehamilan pada restorasi tuba para perempuan yang telah disterilisasi.

Metode: Kajian pustaka.

Hasil: Sterilisasi adalah metode kontrasepsi paling umum di Amerika Serikat, sekitar 39\% perempuan pada usia reproduktif (15 - 44 tahun) menggunakan metode ini. Namun, sekitar 15\% menyesali keputusan mereka untuk melakukan sterilisasi karena pengaruh dari lingkungan mereka dan beberapa faktor, seperti: usia yang muda, kematian anak kandung, kecacatan pada anak, dan pergantian pasangan hidup. Reanastomosis tuba atau restorasi tuba adalah prosedur pembedahan yang bertujuan untuk mengembalikan patensi tuba Fallopi setelah sterilisasi. Hingga saat ini, prosedur modern ini dilakukan dengan melakukan eksisi pada segmen tuba dan melakukan reanastomosis melalui laparoskopi trans-abdominal. Akhir-akhir ini, teknologi laparoskopi telah berkembang dengan pesat seiring dengan ditemukannya laparoskopi berbantu robot. Ada metode alternatif untuk mengembalikan fertilitas pada para perempuan pascasterilisasi yang menyesali keputusan sterilisasi seperti IVF, di mana tidak seperti restorasi tuba yang dilakukan untuk mengembalikan fungsi tuba; IVF dilakukan dengan tujuan untuk melewati fungsi tuba dalam fertilitas. Keuntungan utama dari laparoskopi adalah durasi pascaoperatif yang rendah, adesi pascaoperatif yang lebih rendah, dan laju morbiditas yang menurun. Di samping kerugian utama dari laparoskopi robotik, harga mesin robot dan biaya perawatan mesin yang mahal, ada beberapa keuntungan laparoskopi robotik dibandingkan dengan laparoskopi konvensional, seperti: ketepatan, artikulasi yang lebih tepat dan akurat, tremor yang berkurang, dan visualisasi lapangan operasi yang lebih baik. IVF adalah ciri khas di era ART dan menjadi pilihan alternatif untuk mendapatkan kembali kesuburan pada perempuan yang telah dilakukan sterilisasi tuba.

Kesimpulan: Angka kehamilan dan kelahiran hidup pada prosedur laparoskopi, bedah robotik dan konvensional menunjukkan hasil yang relatif sama. Bedah anastomosis pada perempuan usia kurang dari 40 tahun direkomendasikan dan tindakan laparoskopi restorasi seharusnya dilakukan jika terdapat ahli. Pada perempuan dengan usia lebih dari 40 tahun layak mendapat konseling prosedur IVF.

[Maj Obstet Ginekol Indones 2012; 36-3: 154-60]

Kata kunci: ginekologi, IVF, kehamilan, laparoskopi robotik, reanastomosis, restorasi tuba

Correspondence: Wachyu Hadisaputra, Department of Obstetrics and Gynecology, Dr. Cipto Mangunkusumo Hospital, Jakarta. Telephone : 021-3916249, Email: wachyuhadi@yahoo.com

\section{INTRODUCTION}

Tubal reanastomosis or tubal reversal is a surgical procedure that attempts to restore the fallopian tube patency following sterilization. Females who do not want children anymore choose sterilization as a permanent contraception. Sterilization is considered the most common contraception methods in United States of America, approximately 39\% women in reproductive age (15 - 44 years old) used this method. ${ }^{1}$ However, approximately $15 \%$ 
of these patients deplored this decision due to the influence of their own environment and some factors, such as: young age, the death of a child, the disability of child, and change of partner/remarried. ${ }^{1,2}$ Another consideration to treat the women who wish to become pregnant after having tubal sterilization includes age, cost and the wishes of the couple. The age of the woman is a very important factor in outcome. ${ }^{2-6}$ The probability of poststerilization regret is estimated at $2-13 \%$ but eventually only $1-3 \%$ of the patients have a reversal procedure. ${ }^{7}$ Regardless of the variety of methods, tubal ligation is the most common sterilization procedure. $^{8}$ Thus, for restoration of fertility, tubal reanastomosis is needed. Javakhrisnan et al, 2011 reported that the mean interval between sterilization and recanalization was 6.10 years. ${ }^{4}$ Some factors are determined to influence the outcome of tube reversal. For instances, the increased age is estimated to influence the outcome and the older male partner is associated with the pathology of the tube. ${ }^{2,6}$

Reversal of tubal sterilization represents as one of the best indication for the tubal surgery. In this particular condition, the tubes are in within normal condition; although there is an exception for the obstructed iatrogenic condition whether the tubes are obstructed. The result of the tube reversal relies on the length of the remaining tube after the removal of obstructed segment and the quality of the surgery. The best result of the tube reversal can be obtained in the condition when tube ligation is performed by the clips application in the middle segment of isthmus; meantime the worst result can be obtained by the tube ligation distally which is followed by the removal of the end of fimbriae. ${ }^{9}$ The main concern after having a tubal reversal is ectopic pregnancy. Therefore, patient should be aware about her menstrual cycle and possible pregnancy. Early pregnancy detection and ultrasound evaluation should be done to determine the possibility of ectopic pregnancy. ${ }^{10}$ To date, the modern procedure is performed by doing an excision of the tubal segment and reanastomosis by trans-abdominal laparoscopy. Recently, the laparoscopic technology has developed and evolved rapidly as the robotic assisted laparoscopy was invented to assist the surgeon in doing some laparoscopy procedures despite the paucity publications for this procedure. $8,9,11$

As the new era of assisted reproductive technology (ART) has begun, there is alternative method for restoring the fertility in sterilized women who regretted the decision of being sterilized. In Vitro Fertilization, known as IVF, is the hallmark of this era. Unlike the tubal reversal which is conducted in order to restore the tubal function, the IVF is performed to bypass the function of tubes in fertility. One of the drawbacks of tubal reversal is the requirement of the normal fertility factors, whereas IVF could overcome male infertility by Intracytoplasmic Sperm Injection (ICSI) method or female infertility by stimulating the ovarium with gonadotrophins. ${ }^{3}$ Therefore, for those reasons, tubal surgery has been left behind lately for IVF. Nevertheless, tubal reversal has its own appeal, including the lower risk of multiple births compared with IVF. ${ }^{1}$

\section{INVESTIGATION}

Quick and inexpensive investigations are performed in order to obtain the fertility status of spouse and the reversibility of tubes. The investigations include semen analysis, ovulation status, body basal temperature records, estradiol, day 3 follicle stimulating hormone (FSH), luteinizing hormone (LH), prolactin and testosterone plasma assays, pelvic ultrasound, and hysterosalpingography (HSG) examination. ${ }^{3,12}$ HSG investigation can provide the uterine cavity status and the luminal architecture of the tubes up to site of interruption. It will also indicate the type of prior sterilization, if a clip of a ring was used for this purpose. All of these investigations are important for tubal anastomosis, because it requires the presence of sufficient tubal length and normal or treatable fertility parameters. $^{3}$

Main indication for tubal reanastomosis is the desire for childbearing. However, there are several factors to be considered before doing the procedure. A detailed counseling with both husband and wife should be discussed with the patient. The important factors to be discussed are current age, former tubal ligation technique, risk of complications, success rate, cost, including the possibility of male infertility that can affect pregnancy outcome. Patient also should be informed about the alternative for in vitro fertilization (IVF). ${ }^{4}$ Although laparoscopic surgery said to be better because it is less invasive than laparotomy, but the pregnancy rate outcome is not significantly difference. Male fertility should also be considered in pregnancy outcome. ${ }^{4,10}$ 
There are several factors related to the procedure which have been reported to determine the pregnancy outcome.

- Age of the patient. Women age 40 and less have higher pregnancy rate. Age is the major contributing factor in pregnancy outcome. ${ }^{4,10,13}$

- Tubal ligation method:

- Tubal length.

Poor result are reported in women who has less than $4 \mathrm{~cm}$ tubal length and significantly higher in more than $7 \mathrm{~cm}$ length. ${ }^{4,10,14}$ Therefore, the pregnancy rate was better for laparoscopic sterilization by Falope ring compared to Pomeroy's procedure, which combine ligation and excisition. ${ }^{4,14}$

- Anastomosis site.

A study report that repairing at the interstitial-ampulla site resulting a significantly higher ectopic pregnancy rate compared with other anastomosis sites.

\section{Technical Consideration}

There are two main routes for tubal reanastomosis: laparotomy and laparoscopic surgery. Conventionally, the gold standard for tubal reanastomosis was laparotomy route. The laparoscopic microsurgery has introduced a new dimension for tubal reconstruction as the magnification obtained is similar to that obtained with an operating microscope and it is less invasive. The major advantage for laparoscopic surgery is short postoperative stay duration with minimal tissue handling, less postoperative adhesions, diminish morbidity rate, decreasing post and intra operative blood loss, less of pain medication, and less cosmetic problems. ${ }^{4,8,10}$ Despite of its major drawback, high-cost of robotic machine and machine maintenance; there are advantages of robotic laparoscopy compared to the conventional laparoscopy, such as improved dexterity, more precise and accurate articulation, reduced tremor, and better visualization of the operating field. ${ }^{8,11}$

The main principal for both of the route is to reconnect the fallopian tube using microsurgery technique. This requires fine suturing skill and supporting equipment. In some sophisticated facilities, a remote-controlled robot has been used for assisting surgical procedure. This robot is able to provide a three-dimensional vision that allows the operator to perform ultra precise manipulations with intra abdominal articulated instruments while providing the necessary degrees of freedom. ${ }^{15}$ Nevertheless, the robotically assisted procedure is more time-consuming and more expensive than the open surgical procedure, although the time to normal activity is significantly faster.8,16,17

\section{Laparoscopic Microsurgery vs Laparotomy}

Microsurgical tubal reanastomosis, which has been widely used since 1970s, is one of the tubal reconstruction procedures to restore fertility with the magnification technique similar to an operating microscope. ${ }^{8,18}$ A major benefit of laparoscopic surgery is that it only requires a few small incisions. This means less pain, external scarring and the healing time is faster than traditional open surgery. Hence, laparoscopic surgery nowadays is more considered as a better option than open surgery. ${ }^{18}$

Tan et al (2010) attained that the overall outcomes of both surgical routes have almost similar result. The pregnancy rate and live birth rate in laparoscopy are slightly higher $(77.8 \%$ and $66.7 \%$ respectively) than in conventional open surgery (70.0\% and $60.0 \%$ respectively). In addition, the mean interval time from surgery to pregnancy reduced with laparoscopy (5.5 vs 9 months). This time factor, being an important consideration for any subfertile couple, allows us to counsel patients on their pregnancy chances within a better specific time frame. Nonetheless, there was a higher incidence of ectopic pregnancies and miscarriage in laparoscopy (33.3\% and $33.3 \%$ respectively) than open surgical $(10.0 \%$ and $0 \%$ respectively). The mean surgical duration for laparoscopy ranged from 168.3 minutes to 221.7 minutes. Whereas the mean operating times in laparotomy was 127.8 minutes to 177.2 minutes. Laparoscopy also significantly reduced approximately 2 -fold in the mean hospitalization time. Its approach potentially involved less manipulation of intraperitoneal organs and caused less bleeding. These advantages may result in fewer adhesions and further enhance the pregnancy rate. The outcome was good, as the patient conceived 12 months after surgery. ${ }^{18}$ The other study reported a similar outcome and effectiveness of tubal reversal between laparoscopic approach and open surgery laparotomy approach. There is another difference in term of cost factor between these two tubal reversal procedures 
where the cost of laparoscopic in a day care setting totals $€ 3200$, whereas the cost of the laparotomy ranged $€ 5500-€ 8000 .^{7}$

Schepens et al (2011) conducted a study of 127 patients underwent laparoscopic tubal reanastomosis after regretting sterilization. This study reported the mean net surgery time is within the range of 58-257 min, the 40-month cumulative pregnancy rate was $74 \%$, and the ongoing pregnancy rate was 59\%. Unluckily, there are complications such as ectopic pregnancy (3.9\%) that corresponds to the data of ectopic pregnancy incidence in some literatures (1-7\%). ${ }^{7}$ The other study by Barjot et al (1999) procured that five of 16 women (31.2 \%) who underwent the tubal reversal by laparoscopic approach, followed by 6-month follow up, were having a clinical pregnancy and one of them was having an ectopic pregnancy. ${ }^{12}$

Wiegenrick et al (2005) performed a study to obtain the comparison of fertility outcome between the laparoscopic group and open microsurgery laparotomy. The clinical pregnancy rate in laparoscopic procedure is 20 of 41 women; meanwhile fifteen of them with ongoing pregnancy, four women with a spontaneous abortion, and one woman with ectopic pregnancy. The relatively similar result is obtained in the laparotomy procedure; clinical pregnancy was 26 of 41 women; meantime 24 of them with ongoing pregnancy, one woman with miscarriage, and one woman with ectopic pregnancy. ${ }^{19}$ The study of Jayakhrisnan et al (2011) reported that the pregnancy rate in tubal reversal of Pomeroy tubectomy was $40 \%$, while pregnancy rate of laparoscopic approach was $85.7 \%$. The pregnancy rate of women $\leq 30$ years is $71.4 \%$, as compared with $50 \%$ when age of women was $>30$ years. ${ }^{4}$

The use of robotic-assisted surgery has developed rapidly in recent years as the patient's request of robotic-assisted surgery has increased due to the action of minimally invasive procedures compared with the general open surgery. ${ }^{8}$ Robotic surgery is a surgical technique that bridges between laparoscopy and open surgery on tubal reversal. The costs were similar per delivery and the pregnancy rates were comparable. Moreover, robotic surgery resulted in a shorter hospital stay but longer mean surgical duration (201 minutes), and was associated with a 4-fold increase in ectopic pregnancy rates. It showed that the role of robotic surgery might appear to have some limitations. ${ }^{18}$

\section{IVF vs Tubal Reversal}

IVF and tubal reversal are two treatment options for the women who wish to become pregnant after she had having tubal sterilization. These two procedures have a different approach; unlike the tubal reversal, which is conducted in order to restore the tubal function, the IVF is performed to bypass the function of tubes in fertility. Nevertheless, the only treatment option for women whose Fallopian tubes have been extensively damaged or large portions of their distal segment removed after sterilization procedure and/or the presence of another important fertility factor is IVF. ${ }^{3}$

In United States, IVF demonstrated a further slight improvement in outcomes. The live birth rate per cycle was $28.3 \%$ and live birth rate per embryo transfer was $34.7 \%$. About $82.2 \%$ live birth rate is obtained from cycles that resulted in a clinical pregnancy. Of these, $65.8 \%$ were singleton births and $34.2 \%$ multiple births. ${ }^{3}$ It showed that the major risk of IVF-embryo transfer is multiple pregnancies. Another data compared the outcomes between laparoscopic reversal and IVF in tubal factor infertility for those less than 40 years. The pregnancy and live birth rates were higher in laparoscopy $(77.8 \%$ and $66.7 \%$ respectively) than IVF ( $46.8 \%$ and $34.6 \%$ respectively). Even though the rates of miscarriage and ectopic pregnancy were higher $(33.0 \%$ and $33.0 \%)$ in tubal reversal, this procedure does not have any tendency of increasing multiple pregnancy risk. ${ }^{18}$ Furthermore, tubal reversal is considered to relatively prevent multiple pregnancy compared to IVF. Moreover, women are able to conceive in every cycle without requiring further treatment, and it is possible to have more than one pregnancy after reversal of tubal sterilization.

In spite of several advantages of tubal reversal, which had been discovered, we need to realize some possible disadvantages in surgical technique. These include a delayed time to pregnancy, increase risk of ectopic pregnancy, potential for further adhesion formation and surgical risks. Nevertheless, the important thing to remember when considering surgery over IVF is the pregnancy outcome cannot be fully expected for 2 to 4 years after the procedure. The maximal success was attained at 46 months and 60 months with laparoscopy and open surgery respectively. ${ }^{18}$ Tubal re-anastomosis, considered to restore a normal tubal patency, may lead to a cumulative pregnancy rate better than the 

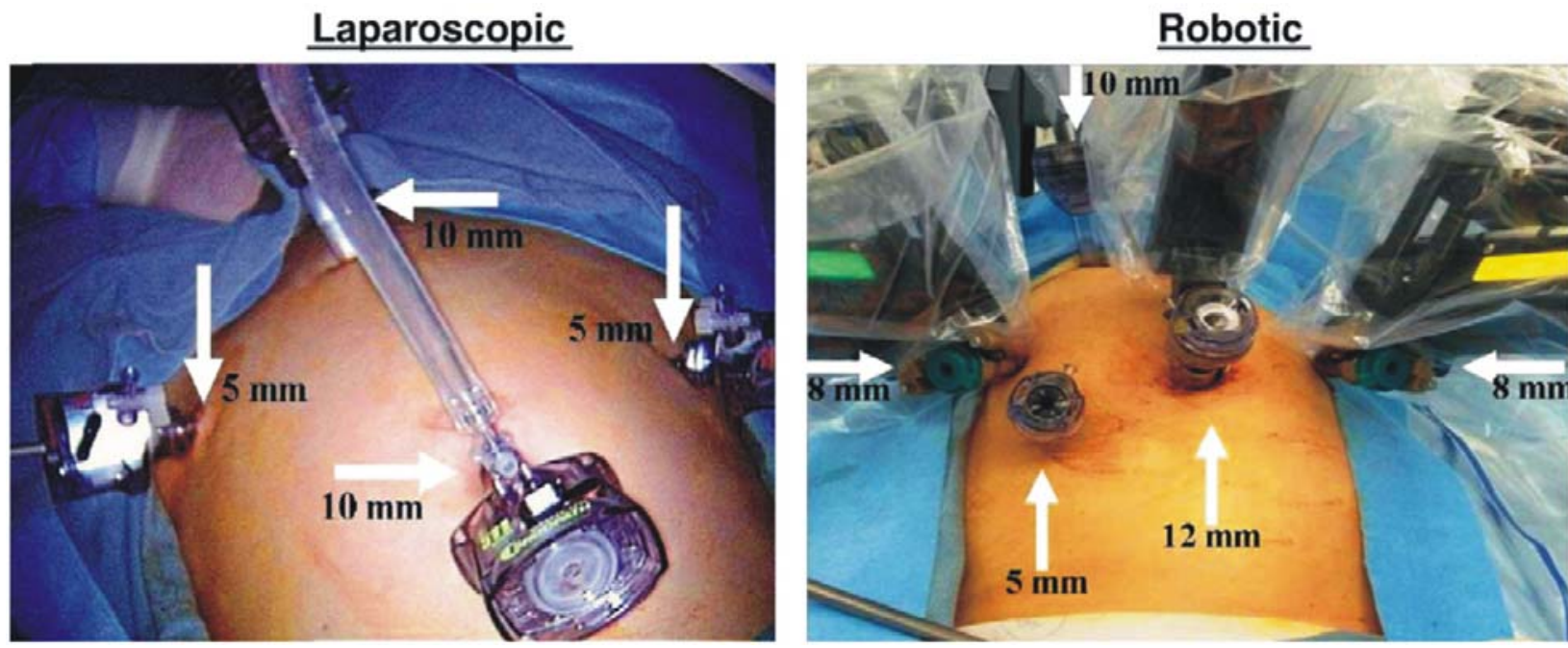

Figure 1. The comparison of conventional laparoscopy and robotic laparoscopy. 20

chances offered by one or two IVF attempts. After the age of 42 , the pregnancy rate after intrauterine insemination is superior to IVF $(8.1 \%$ and $4.7 \%$, respectively). ${ }^{9}$ Hence, it might be reasonable to counsel IVF with any couple without pregnancy 12 months after tubal surgery or with the over-40years-old women.

\section{Robotic-assisted Laparoscopy}

Laparoscopy has evolved with the new technologies; such as camera-technology and human resources which allow laparoscopy to replace the invasive laparotomy. In gynecology, laparoscopy has given the role of optimizing the procedures that are used to be handled with conventional open surgery laparotomy. Robotic-assisted surgery is the newest modification of laparoscopic approach in minimally invasive surgery (Figure 1).

In 1999, Falcone reported that the first tubal reanastomosis procedures has already been successfully assisted by robotic system. ${ }^{20}$ The procedure was conducted in all patients without complications. The mean operative time was $159 \pm 33.8$ minutes with the pregnancy rate is $89 \%$ and $50 \%$ in 6- and 12- month follow-up respectively. The longer time of procedure leads to decreased surgical precision from surgeon's fatigue; moreover conventional laparoscopy leads to unsatisfied depth of perception, disturbance of the eye-hand-target axis, the fulcrum effect, limited degrees of movement, and less tactile feedback. ${ }^{21-24}$ Robotic technology has been considered to overcome these drawbacks. Robotic-assisted laparoscopy is recommended in advanced pathology, such as pelvic ad- hesions of which the scarred or obliterated anterior cul-de sac, because the demand of minimally invasive surgery. Meanwhile there are some limitations, including the surgery field, surgeon's skill, and technical skill in conventional laparoscopy. ${ }^{25,26}$ Therefore, despite its advantages, there are some drawbacks of robotic-assisted laparoscopy such as cost, bulky size, lack of haptic feedback, limited instrumentation, and larger required incisions. ${ }^{27-29}$

Da Vinci Surgical System, one of FDA-approved robotic system currently on the market, has three main components: surgical cart, vision cart, and surgeon's console. ${ }^{30,31}$ Jakarta, the capital city of Indonesia, had already installed one unit of Da Vinci System in Bunda Hospital since January 2012 and became the milestone of robotic-assisted laparoscopic approach in Indonesia. ${ }^{8}$ The high cost is the major drawback of robotic surgery. ${ }^{29}$ As a comparison, the cost of Da Vinci robot is $€ 1.5$ million (US\$ 1 million - US\$2.5 million) per unit, the maintenance cost $€ 150,000$ annually, and cost for disposable robotic instrument is $\$ 2,210$; meanwhile disposable instrument in conventional laparoscopy is \$1,138. ${ }^{31-33}$

Holloway et al (2009) reported the multiple review studies that is comparing between roboticassisted laparoscopy and open laparotomy for tubal anastomosis. This review attained the result that robotic-assisted procedure has greatly increased operative times. Nevertheless, length of hospital stay, recovery time, and time to return to independent activities of daily living were significantly shorter as compared to the open laparotomy. ${ }^{34}$ The total operative times of robotic sur- 
gery system consists of docking time and console time; resulted in the longer operative time than conventional laparoscopy and laparotomy. 35

Sarlos et al (2010) reported that the mean operative time of robotic-assisted laparoscopy surgery requires a longer time than the mean operative time of conventional laparoscopy (108.9 minutes and 82.9 minutes respectively) and the total intra operative blood loss of robotic laparoscopy is greater than conventional laparoscopy $(81 \mathrm{ml}$ and $<50 \mathrm{ml}$ respectively). Meanwhile, there is no significant difference for the length of stay between robotic laparoscopy and conventional laparoscopy (3.3 days vs 3.9 days). ${ }^{36}$ Pasic et al (2010) obtained a relatively same results: that the total operative cost in robotic laparoscopy is more expensive than conventional laparoscopy. There is no significant difference between robotic laparoscopy and conventional laparoscopy in terms of operative time and length of stay. ${ }^{37}$ Robotic-assisted procedures resulted in increased operative time as well as increased estimated blood loss, although not clinically significant, without considerable improvement in clinical outcomes. ${ }^{34}$ Further studies are needed in order to compare conventional laparoscopy and robotic surgery to determine if robotic technology is more beneficial in sterilization reversal by assessing operative time, patient satisfaction, and pregnancy outcome.

\section{CONCLUSION}

Tubal reanastomosis is one of the procedures that can help women to regain fertility after tubal ligation. This procedure is considered to restore the function of Fallopian tubes. This procedure could be performed by either open laparotomy microsurgery or laparoscopy. As technology expands, the laparoscopy had been modified to be a robotic approach by the invention of the latest robotic laparoscopy system - Da Vinci System. The other approach of reversing the fertility function of sterilized women is In Vitro Fertilization (IVF), which replaces the function of tubes.

The expected fertility outcome is the increase of pregnancy and live birth rate, which correspond to treatment success. Relatively similar value of pregnancy rate and live birth rate were obtained in laparoscopy, robotic and open surgery. The laparoscopic tubal surgery has shorter hospitalization time than open microsurgery laparotomy. On the other hand the mean operating time of laparoscopy is longer than open microsurgery laparotomy. Less manipulation and gentle handling of tissues during procedure decline the incidence of bleeding and adhesion in laparoscopic approach. Furthermore, it can also reduce post-operative pain and analgesia requirements. The patients are able to return to normal activity immediately after the laparoscopic procedure. Even though laparoscopic has several advantages, incidence of ectopic pregnancy is higher than in open surgery. Similar to the superiority of laparoscopy, robotic surgery also has shorter hospitalization time than laparotomy, but robotic laparoscopy has a longer mean operating time compared to laparotomy. Moreover, estimated average treatment cost with laparoscopy was lower than with open and robotic surgery in those the pregnancy and live birth rate was similar.

Surgical reversal to patients younger than 40 years is recommended and laparoscopic reversal should be conducted if there are any experts to reduce morbidity. Whereas in older patients where the fecundity matters has reduced, IVF is still the superior option although the pregnancy and live birth rate were higher in laparoscopy and associated with the increase of multiple pregnancy risk. Patients should be well informed about and her own conditions, the spouse, and the choices of alternatives for having a child to make the best decision. In addition, the gynecologist must use an effective method of sterilization to minimize the failure rates, but also consider a good preservation of length and anastomosis site, should the patient's circumstances change and they desire to regain fertility.

\section{REFERENCES}

1. Bedaiwy MA, Barakat EM, Falcone T. Robotic tubal anastomosis: technical aspects. JSLS. 2011; 15(1):10-5.

2. Cohen MA, Chang PL, Uhler M, Legro R, Sauer MV, Lindheim SR. Reproductive outcome after sterilization reversal in women of advanced reproductive age. J Assist Reprod Genet. 1999; 16(8):402-4.

3. Gomel V. Reversal of tubal sterilization versus IVF in the era of assisted reproductive technology: a clinical dilemma. Reprod Biomed Online. 2007; 15(4):403-7.

4. Jayakrishnan K, Baheti SN. Laparoscopic tubal sterilization reversal and fertility outcomes. J Hum Reprod Sci. 2011; $4(3): 125-9$.

5. Ludermir AB, Machado KM, Costa AM, Alves SV, Araujo TV. Tubal ligation regret and related risk factors: findings from a case-control study in Pernambuco State, Brazil. Cadernos de saude publica/Ministerio da Saude, Fundacao Oswaldo Cruz, Escola Nacional de Saude Publica. 2009;25(6):1361-8. 
6. Wilcox LS, Chu SY, Peterson HB. Characteristics of women who considered or obtained tubal reanastomosis: results from a prospective study of tubal sterilization. Obstet Gynecol. 1990; 75(4):661-5.

7. Schepens JJ, Mol BW, Wiegerinck MA, Houterman S, Koks CA. Pregnancy outcomes and prognostic factors from tubal sterilization reversal by sutureless laparoscopical re-anastomosis: a retrospective cohort study. Hum Reprod. 2011; 26(2):354-9.

8. Hadisaputra W, Pratama YS. Laparoscopic robotic surgery in gynecology. Indones J Obstet Gynecol. 2011;35(3):146-50.

9. Watrelot A, Chauvin G. Current practice in tubal surgery and adhesion management: a review. Reprod Biomed Online. 2011; 23(1):53-62.

10. la Grange J, Kruger TF, Steyn DW, van der Merwe JP, Siebert I, Matsaseng T, et al. Fallopian tube reanastomosis by laparotomy versus laparoscopy: a meta-analysis. Gynecol Obstet Invest. 2012; 74(1):28-34.

11. Nick AM, Ramirez PT. The impact of robotic surgery on gynecologic oncology. J Gynecol Oncol. 2011;22(3):196-202.

12. Barjot PJ, Marie G, Von Theobald P. Laparoscopic tubal anastomosis and reversal of sterilization. Hum Reprod. 1999; 14(5):1222-5.

13. Moon HS, Joo BS, Park GS, Moon SE, Kim SG, Koo JS. High pregnancy rate after microsurgical tubal reanastomosis by temporary loose parallel 4-quadrant sutures technique: a long long-term follow-up report on 961 cases. Hum Reprod. 2012; 27(6):1657-62.

14. Deffieux X, Morin Surroca M, Faivre E, Pages F, Fernandez $\mathrm{H}$, Gervaise A. Tubal anastomosis after tubal sterilization: a review. Arch Gynecol Obstet. 2011; 283(5):1149-58.

15. Degueldre M, Vandromme J, Huong PT, Cadiere GB. Robotically assisted laparoscopic microsurgical tubal reanastomosis: a feasibility study. Fertil Steril. 2000; 74(5):1020-3.

16. Vlahos NF, Bankowski BJ, King JA, Shiller DA. Laparoscopic tubal reanastomosis using robotics: experience from a teaching institution. J Laparoendosc Adv Surg Tech A. 2007; 17(2):180-5.

17. Rodgers AK, Goldberg JM, Hammel JP, Falcone T. Tubal anastomosis by robotic compared with outpatient minilaparotomy. Obstet Gynecol. 2007; 109(6):1375-80.

18. Tan HH, Loh SF. Microsurgical reversal of sterilisation - is this still clinically relevant today? Ann Acad Med Singapore. 2010; 39(1):22-6.

19. Wiegerinck MA, Roukema M, van Kessel PH, Mol BW. Sutureless re-anastomosis by laparoscopy versus microsurgical re-anastomosis by laparotomy for sterilization reversal: a matched cohort study. Hum Reprod. 2005; 20(8):2355-8.

20. Nezhat F. Minimally invasive surgery in gynecologic oncology: laparoscopy versus robotics. Gynecol Oncol. 2008; 111(2 Suppl):S29-32.

21. Kim YT, Kim SW, Jung YW. Robotic surgery in gynecologic field. Yonsei Med J. 2008; 49(6):886-90.
22. Anderberg M, Larsson J, Kockum CC, Arnbjornsson E. Robotics versus laparoscopy-an experimental study of the transfer effect in maiden users. Ann Surg Innov Res. 2010. 4:3.

23. Schreuder HW, Verheijen RH. Robotic surgery. BJOG: Int J Obstet Gynecol. 2009; 116(2):198-213.

24. Bedaiwy MA, Volsky J, Sandadi S, Fader AN. The expanding spectrum of robotic gynecologic surgery : a review. Middle East Fertil Soc J. 2011; 11(2):1-9.

25. Advincula AP, Reynolds RK. The use of robot-assisted laparoscopic hysterectomy in the patient with a scarred or obliterated anterior cul-de-sac. JSLS. 2005; 9(3):287-91.

26. Mao SP, Lai HC, Chang FW, Yu MH, Chang CC. Laparoscopyassisted robotic myomectomy using the da Vinci system. Taiwan J Obstet Gynecol. 2007; 46(2):174-6.

27. Lambaudie E, Narducci F, Bannier M, Jauffret C, Pouget $N$ Leblanc E, et al. Role of robot-assisted laparoscopy in adjuvant surgery for locally advanced cervical cancer. Eur J Surg Oncol. 2010; 36(4):409-13.

28. Nezhat C, Saberi NS, Shahmohamady B, Nezhat F. Roboticassisted laparoscopy in gynecological surgery. JSLS. 2006; 10(3):317-20.

29. van Dam P, Hauspy J, Verkinderen L, Trinh XB, van Dam PJ, Van Looy L, et al. Are costs of robot-assisted surgery warranted for gynecological procedures? Obstet Gynecol Int. 2011:973830.

30. Hashizume M, Tsugawa K. Robotic surgery and cancer: the present state, problems and future vision. Jpn J Clin Oncol. 2004; 34(5):227-37.

31. Dam Pv, Hauspy J, Verkinderen L, Trinh XB, Dam P-Jv, Looy Lv, et al. Are Costs of Robot-Assisted Surgery Warranted for Gynecological Procedures? Obstet Gynecol Int. 2011:1-6.

32. Barbash GI, Glied SA. New technology and health care costs-the case of robot-assisted surgery. EngJ Med. 2010; 363(8):701-4.

33. Nick AM, Ramirez PT. The impact of robotic surgery on gynecologic oncology. J Gynecol Oncol. 2011; 22(3):196-202.

34. Holloway RW, Patel SD, Ahmad S. Robotic surgery in gynecology. Scandinavian J Surg. 2009; 98(2):96-109.

35. Renato S, Mohamed M, Serena S, Giulia M, Giulia F, Giulia $\mathrm{G}$, et al. Robot-assisted radical hysterectomy for cervical cancer: review of surgical and oncological outcomes. ISRN Obstet Gynecol. 2011:872434.

36. Sarlos D, Kots L, Stevanovic N, Schaer G. Robotic hysterectomy versus conventional laparoscopic hysterectomy: outcome and cost analyses of a matched case-control study. Eur J Obstet Gynecol Reprod Biol. 2010; 150(1):92-6.

37. Pasic RP, Rizzo JA, Fang H, Ross S, Moore M, Gunnarsson C. Comparing robot-assisted with conventional laparoscopic hysterectomy: impact on cost and clinical outcomes. J Minim Invasive Gynecol. 2010; 17(6):730-8. 